\title{
Interannual and daily activity patterns of mid-sized mammals in Maracaibo Lake Basin, Venezuela
}

\author{
Lisandro Morán ${ }^{1}$, Luis García ${ }^{1,2}$, José D. Ferrebuz ${ }^{1,2}$, Roxana Sánchez ${ }^{1,2}$, Ada Sánchez-Mercado ${ }^{1,3}$, Alberto Porta and José R. Ferrer-Paris ${ }^{1 *}$ \\ ${ }^{1}$ Laboratorio de Ecología Espacial. Centro de Estudios Botánicos y Agroforestales. Instituto Venezolano de Investigaciones Científicas \\ (IVIC). Apartado Postal 20632, ZP 1020-A, Caracas, Venezuela. Email: leucemio17@gmail.com (LM); jr.ferrer.paris@gmail.com (JRFP). \\ 2 Escuela de Biología, Universidad del Zulia, Avenida Universidad, Facultad Experimental de Ciencias, Bloque A1, planta alta. \\ Apartado Postal 526, ZP 4005, Maracaibo, Venezuela. Email: Imgg.luz@gmail.com (LG); ferrebuz 95@hotmail.com (JDF); \\ roxanasz.19@gmail.com (RS). \\ ${ }^{3}$ Provita, Calle La Joya con Avenida Libertador, Unidad Técnica del Este, piso 10, oficina 29-30, Chacao, ZP 1060,Caracas, Venezuela. \\ Email: ay.sanchez.mercado@gmail.com (ASM). \\ ${ }^{4}$ Fundación Científica ARA MACAO Apartado Postal 94, San Carlos ZP 2201, Cojedes, Venezuela. Email: capitanporta@gmail.com (AP). \\ * Autor de correspondencia
}

Despite its biogeographic importance, the mammals of Maracaibo lake basin have been poorly studied. The objectives of this study were to: 1) provide a list of the mammal species detected by combining information from camera traps and other sources, and 2) describe diurnal and annual activity patterns for some of the species detected. Camera-trapping was carried out for one year in five localities within the Burro Negro Protection Zone (Spanish acronym ZPBN). Records of terrestrial mammals (excluding Chiroptera) were compiled from: 1) direct and indirect opportunistic records during field visits, 2) informal interviews with local inhabitants, 3) three national natural history collections, and 4) scientific literature. The complementarity between sources, similarity with other localities within the region, and temporal changes in composition were evaluated with the Sørensen Similarity Index (RS), and annual differences in the number of detections per sampling effort were evaluated using a $X^{2}$ test. Sampling effort was 1,799 camera days, resulting in 569 events of mammal detection recorded and 20 species from 17 families in 9 orders identified. Four species (Dasypus novemcinctus, Dasyprocta leporina, Cerdocyon thous and Leopardus pardalis) were captured all year round. Camera traps detected half of the non-flying mammal species in the area, including five that had not been previously reported by other sources (Cuniculus paca, Coendou prehensilis, Sylvilagus floridanus, Procyon cancrivorus and Puma yagouaroundi). At least three species (Panthera onca, Odocoileus virginianus, and Hydrochoerus hydrochaeris) had been reported as historically abundant, but were not detected during the year of camera trapping, which could be due to recent declines in their populations. Camera trapping provides reliable records on the presence of four species with data gaps in their distribution ranges (Myrmecophaga tetradactyla, Coendou prehensilis, Cerdocyon thous and Procyon cancrivorus), as well as baseline data for evaluating the distribution overlap between pairs of species, such as Tamandua mexicana and T. tetradactyla, and Dasyprocta leporina and D. punctata. A higher species richness was observed between June and August, in the rainy season.

A pesar de su importancia biogeográfica, la mastofauna de la cuenca del Maracaibo sólo se conoce parcialmente. Los objetivos del presente trabajo eran: 1) elaborar una lista de especies de mamíferos terrestres combinando el fototrampeo con otras fuentes de información, y 2) describir patrones de actividad diarios y anuales para algunas de las especies detectadas. Se realizó fototrampeo durante un año en cinco localidades dentro de la Zona Protectora de Burro Negro (ZPBN). Se compilaron registros de presencia de mamíferos terrestres (excluyendo quirópteros) de: 1) muestreos no sistemáticos de indicios indirectos y directos, 2) entrevistas informales a habitantes locales, 3) tres colecciones zoológicas nacionales, y 4) literatura científica. Se evaluó la complementariedad entre fuentes, similitud entre localidades o cambios temporales en composición con el índice de Sørensen (RS) y los cambios en el número de detecciones a lo largo del año según el esfuerzo de muestreo mensual con una prueba $x^{2}$. El esfuerzo de muestreo fue de 1,799 días-cámara, se registraron 569 eventos de presencia de mamíferos. Se identificaron 20 especies de 17 familias y 9 órdenes. Cuatro especies (Dasypus novemcinctus, Dasyprocta leporina, Cerdocyon thous, Procyon cancrivorus y Leopardus pardalis) fueron detectadas constantemente durante el año. El fototrampeo detectó la mitad de las especies no voladoras conocidas en la zona, incluyendo cinco no reportadas por otras fuentes (Cuniculus paca, Coendou prehensilis, Sylvilagus floridanus y Puma yagouaroundi). Especies como Panthera onca, Odocoileus virginianus y Hydrochoerus hydrochaeris eran históricamente abundantes, pero no pudieron ser detectadas, lo que podría sugerir disminución en las poblaciones. Se aportan registros de presencia para cuatro especies con información vacíos de (Myrmecophaga tetradactyla, Coendou prehensilis, Cerdocyon thous y Procyon cancrivorus), aún se debe evaluar el solapamiento en la distribución de varias especies, como por ejemplo las dos especies de Tamandua y las dos especies de Dasyprocta. La mayor riqueza se observó entre junio y agosto que correspondió a la fase inicial del periodo de lluvias.

Key words: Camera trapping; diurnal activity; inventory; monitoring; seasonality.

(C) 2018 Asociación Mexicana de Mastozoología, www.mastozoologiamexicana.org

\section{Introduction}

From the biogeographical point of view, the Maracaibo basin is a center of biotic complexity and phylogenetic diversity within the Neotropics, influenced by two centers of maximum convergence of endemism areas: the province of Maracaibo in the Colombian-Venezuelan La Guajira, and the North-Andean province (Ruggiero et al. 1998; NogueraUrbano and Escalante 2015). However, the floristic and faunistic aspects on the eastern coast of this basin have been little studied (Smith and Field 2001; González-Fernández and Nieves 2011; Pietrangeli et al. 2011). 
One of the few remnants of natural forest vegetation in the Maracaibo lake eastern coast spreads around the Pueblo Viejo dam, also known as Burro Negro, in the southwestern slope of Serrania del Empalado. Despite its location within the Pueblo Viejo Hydraulic National Reserve and the Burro Negro Protected Zone (Bevilacqua et al. 2006), this forest area is facing serious pressure from deforestation, forest fires, and indiscriminate wildlife exploitation (Consejo Zuliano de Planificación 1975; Rodríguez et al. 2010; Pietrangeli et al. 2011; Portillo-Quintero et al. 2012; Ferrer-Paris 2016a). On the northern slopes of the Burro Negro Protected Zone (Socopó, Río Socopito), where forest fragmentation is greatest, at least 37 mammal species have been reported, excluding bats. This list is based primarily on field sampling (González-Fernández and Nieves 2011) and literature reviews (Handley 1976; Linares 1998). On the Burro Negro southern slope, where the best preserved forest patch is located, no inventories of fauna have been published to date.

The use of automated photographic capture systems, also referred to as camera trapping, allows a non-invasive recording of the presence of terrestrial non-arboreal vertebrates over extended periods of time and in hard-to-access places, thus improving the power to detect nocturnal or cryptic species, and is also an effective alternative to traditional methods (Barea-Azcon et al. 2007; Balme et al. 2009; Roberts 2011).

In the present work, we contribute to the knowledge of the fauna in Venezuela by building an inventory of medium- and large-sized terrestrial mammals inhabiting an area of interest for conservation and biogeographical studies that currently shows biological information gaps. We applied the camera-trapping method to monitor for a year the terrestrial fauna of a sector of the Pueblo Viejo Hydraulic National Reserve and the Burro Negro Protected Zone. We developed a list of the species observed by combining camera-trapping with other data sources (zoological collections, bibliography, direct and indirect sightings, and interviews), and used photographic records to describe daily and annual activity patterns for some species.

\section{Methods}

Study Area. The study area is located within the Burro Negro Recreation Park and the Pueblo Viejo Hydraulic National Reserve that comprises an extension of 75,000 ha, and overlaps with the Burro Negro Protected Zone between coordinates $10.17445^{\circ} \mathrm{N},-71.04636^{\circ} \mathrm{W}$ and $10.22054^{\circ} \mathrm{N}$, $-71.02438^{\circ} \mathrm{W}$, in the municipalities of Lagunillas (Parroquia Campo Lara) and Valmore Rodríguez (Parroquia Raúl Cuenca; Figure 1a). Mean annual temperature is $27.4{ }^{\circ} \mathrm{C}$. Mean annual precipitation ranges from 450 to $1,500 \mathrm{~mm}$, characterized by a marked seasonality, with $60 \%$ to $80 \%$ of annual precipitation from May to October (Plan Bonito Station Series No. 1083, 1956-1983; data from INAMEH; http:// www.inameh.gob.ve).

The natural vegetation comprises seasonal deciduous and semi-evergreen forests, with a floristic richness of over

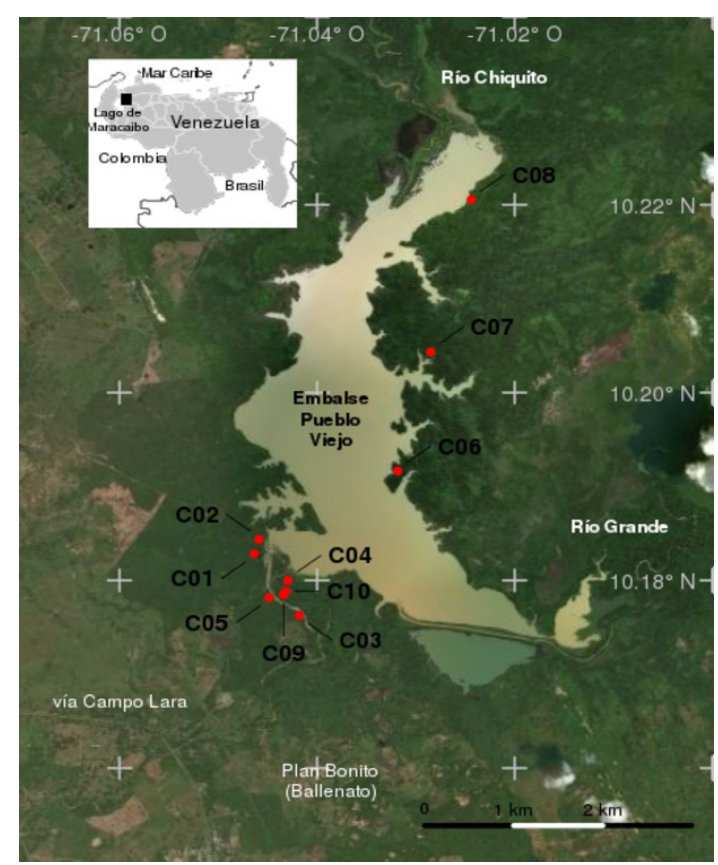

Figure 1. Study area and location of camera traps. Geographic location of the Pueblo Viejo dam in the municipality of Lagunillas, Zulia, Venezuela, and detail of the study area showing sampling localities (CO1 to $\mathrm{C} 10$ ). Source of the satellite image: Microsoft Bing Maps Imagery Service API (reviewed on 10 December 2017; Burro Negro, Venezuela, between coordinates 10.17445' $00^{\prime \prime} \mathrm{N},-71.0463611^{\prime \prime} \mathrm{W}$ and $1024^{\prime \prime} \mathrm{N}, 71^{\circ} 00^{\prime \prime}$ 00 "W $10.22054 \mathrm{~N},-71.02438 \mathrm{~W}$ ).

250 species of plants, dominated by species of the families Leguminosae, Bignoniaceae, Sapindaceae, and Malvaceae (Pietrangeli et al. 2011). The western bank of the dam is surrounded by large deforested areas, cleared for livestock grazing activities and, to a lesser extent, for agriculture (Pietrangeli et al. 2011). This zone is also subjected to periodic burning by farmers as a weed-control measure and illegal wildlife poaching method (pers. obs. Lisandro Morán; Consejo Zuliano de Planificación 1975; Ferrer-Paris 2016a). The main human settlements are located to the west of the dam and consist of scattered hamlets with low population densities (10 to 20 inhabitants $/ \mathrm{km}^{2}$; Fuenmayor 2005; Ferrer-Paris 2016b).

Camera-trapping. Five sampling localities were selected for the monitoring of the Pueblo Viejo dam western bank, which were separated by an average distance of $328 \mathrm{~m}(61$ m minimum; 440 m maximum; Figure 1). These were spread across an area of 83 ha calculated by superimposing operating ranges of 20 ha around each individual camera and taking into account the overlap between these. This first group of five cameras was in operation for a year and, given the proximity between them, are more likely to have captured the same individual on several occasions. We identified three localities on the eastern bank (C06, C07 and C08) separated by an average distance of 1,690 $\mathrm{m}$ (1,480 to 1,910 $\mathrm{m})$, which were sampled during the first period only (Table 1). Because of their isolation, these captured relatively independent samples that covered a total area of approximately 60 ha. Localities C01 and C03 were relocated to C09 and $\mathrm{C} 10$ for the second sampling period to ensure a better protection of the equipment. 
The criteria for selecting sampling localities were: 1) accessibility by water, road or trails throughout the year; 2 ) indirect evidence of the presence of fauna (e. g., feces, footprints etc.); 3) forest coverage and composition; 4) proximity to water sources; 5 ) proximity to potential shelter areas for wildlife.

In each sampling locality, one trap camera (Bushnell, Ltl Acorn, Moultrie and Cuddeback) was set on a tree at $\sim 40 \mathrm{~cm}$ from the ground, facing the potential route of displacement of animals, and approximately at $3 \mathrm{~m}$ from the intended photo capture site. Cameras were in operation during six periods of variable duration (Table 1). At the end of each period, the memory and batteries of cameras were replaced and the information was backed up.

In each sampling station, we recorded the latitude, longitude, elevation, forest cover, understorey density, topography, soil type, and disturbance. Images captured by each camera were downloaded and organized in a relational database, including image metadata, notes and subsequent identifications. The database was used to elaborate tables that summarize the information for each camera according to the effective number of days of operation, and the number of photos and events in each period (Table 1). Photographs were grouped into detection events, each defined as a sequence of consecutive photos separated by less than 1 minute between them. For each event, we identified the species detected using the morphological description and the distribution information outlined in Linares (1998). Percentages of certainty of identification were set based on: 1) image quality, as a percentage established by the identifier according to the degree of sharpness ( $0 \%$ unfocused -100 $\%$ very sharp), contrast ( $0 \%$ very dark $-100 \%$ optimal contrast), and frame (0\% partial image of the animal - $100 \%$ complete image); 2) percentage of identification of distinctive features of the species, such as spot patterns, number of rings, pelage color, etc. (Reyes et al. 2017). The degree of certainty assigned to a photo is the average of the percent sharpness, contrast, frame, and degree of identification of distinctive features. In addition, we noted descriptions of evidence of reproductive events such as mating, presence

Table 1. Camera-trap Sampling Effort. The coordinates of each locality, start and end dates of each sampling period, and the number of images/events per camera captured in each sampling period. *Periods with no images due to camera operation issues.

\begin{tabular}{lccccccc}
\hline & & Period 1 & Period 2 & Period 3 & Period 4 & Period 5 & Period 6 \\
& & & & & \\
& & & & & \\
Camera & Coordinates & $07 / 16 / 16$ & $07 / 09 / 16$ & $08 / 10 / 16$ & $09 / 14 / 16$ & $11 / 10 / 16$ & $03 / 04 / 17$ \\
\hline C01 & $10.18282,-71.04636$ & $139 / 17$ & & & & & \\
C02 & $10.18439,-71.04589$ & $455 / 92$ & $33 / 9$ & $466 / 60$ & $216 / 42$ & $495 / 74$ & $5319 / 356$ \\
C03 & $10.17628,-71.04179$ & $*$ & & & & & \\
C04 & $10.17999,-71.04295$ & $105 / 15$ & $*$ & $*$ & $*$ & $386 / 63$ & $24 / 6$ \\
C05 & $10.17817,-71.04486$ & $160 / 35$ & $91 / 27$ & $299 / 70$ & $76 / 19$ & $227 / 47$ & $4245 / 589$ \\
C06 & $10.19164,-71.03184$ & $19 / 4$ & & & & & \\
C07 & $10.20433,-71.02850$ & $180 / 39$ & & & & & \\
C08 & $10.22054,-71.02438$ & $71 / 13$ & & & & & \\
C09 & $10.17445,-71.04340$ & & $160 / 30$ & $144 / 26$ & $907 / 182$ & $495 / 93$ & $961 / 1358$ \\
C10 & $10.17884-71.04315$ & & $*$ & $36 / 10$ & $69 / 12$ & $30 / 6$ & $5068 / 1358$ \\
\hline
\end{tabular}

of pairs of adults or adults with offspring (Ouboter and Kadosoe 2016).

Additional Sources of Presence Records. Records on the presence of species of non-flying terrestrial mammals in Burro Negro were compiled from the following sources: 1) non-systematic sampling of indirect evidence (footprints and traces) and direct observations; 2) semi-structured interviews with local inhabitants and staff of Instituto Nacional de Parques (National Institute of Parks; INPARQUES); 3) national zoological collections of La Salle Museum of Natural History (MHNLA), Museum of the Rancho Grande Biological Field Station (EBRG), Collection of Vertebrates at University of Los Andes (CVULA), Museum of Biology at University of Zulia (MBLUZ); 4) scientific literature.

Field trips for revision of camera traps included non-systematic samplings when trails adjacent to sampling localities were walked. All samplings were conducted during the day and consisted of recording and identification of prints and traces based on size and shape (Navarro and Muñoz 2000). In direct sightings, specimens were identified in the field by two persons based on the description of Linares (1998). In all cases, the geographical coordinates, date and time of sighting were recorded. During that same period of time, semi-structured interviews were held with 40 persons, including INPARQUES staff and local inhabitants of nearby towns (Plan Bonito and Campo Mara) that use the dam frequently, who were questioned about the mammals observed by them during their regular visits to the area. During interviews, species were identified using illustrations and photographs of the species potentially present in the area (Linares 1998).

Of the four biological collections reviewed, only three (MHNLA, EBRG and MBLUZ) had records of terrestrial mammals sampled in "Burro Negro", "Embalse Pueblo Viejo" or other equivalent locality names. The only literature sources found for the area were the work of Osgood (1912) that refers to El Panorama and El Empalado, located at 50-70 $\mathrm{km}$ away from the study area before the construction of the dam, and a review of the fauna of Venezuela by Linares (1998), a work with distribution maps that include records of observations and collections for the study area, albeit of low cartographic accuracy. The list of species compiled for the study area was compared with two preliminary lists of mammals for the hills of the northern slope of Serranía de Ziruma (González-Fernández and Nieves 2011) and for Serrania de Baragua (Sanchez et al. 1995), located $90 \mathrm{~km}$ to the east-northeast. For all taxonomic lists and comparisons, we used the nomenclature of Wilson and Reeder (2005), except for species of the genus Mazama (Gutiérrez et al. 2017).

Data Analysis. The frequency of daily and monthly occurrence of each species detected was estimated as the number of photographic events by species divided by the sampling effort conducted at each time of the day or month. A list of adult+offspring or mating events was elaborated. For species with more than 40 detections, we conducted $a x^{2}$ test of observed vs. expected values accord- 
ing to the monthly sampling effort. The complementarity between sources, similarity between localities, or temporary changes in composition, was assessed using the Sørensen index (Legendre and Legendre 1998).

\section{Results}

The total effective sampling effort of camera trapping was 1,799 camera days (Table 1 ), representing $87.7 \%$ of the initial estimated effort (2,051 camera days). This difference was due to operational errors of cameras (i. e., memory, mechanical and configuration issues), and the theft of one camera during the sampling period.

A total of 3,356 photographic events were obtained, divided into 2,506 (74.7 \%) false positives, 101 (3.0\%) events involving the detection of other animals (birds, reptiles, amphibians), 132 (3.9\%) partial images that did not allow an unambiguous identification, and 569 (17.0\%) records of mammals suitable for identification to species. We identified 20 species of 17 families and 9 orders (Table 2). Of the total number of mammal recording events, 74.7 $\%$ were identified with high certainty (> $80 \%), 22.3 \%$ with intermediate certainty (50\% to $80 \%$ ), and $2.9 \%$ with low certainty $(<50 \%)$. The species that were most difficult to identify were the two species of Mazama, given their similar characteristics, while Didelphis marsupialis, Cebus albifrons, Dasyprocta leporina, Cerdocyon thous, and Leopardus pardalis had events of both high and low certainty, mainly due to differences in illumination or framing (Figure 2).

In addition to the 20 species detected by camera traps, direct or indirect evidence of the presence of other species (Panthera onca, Hydrochoerus hydrochaeris, Pecari tajacu and Conepatus semistriatus) was also observed, for a total

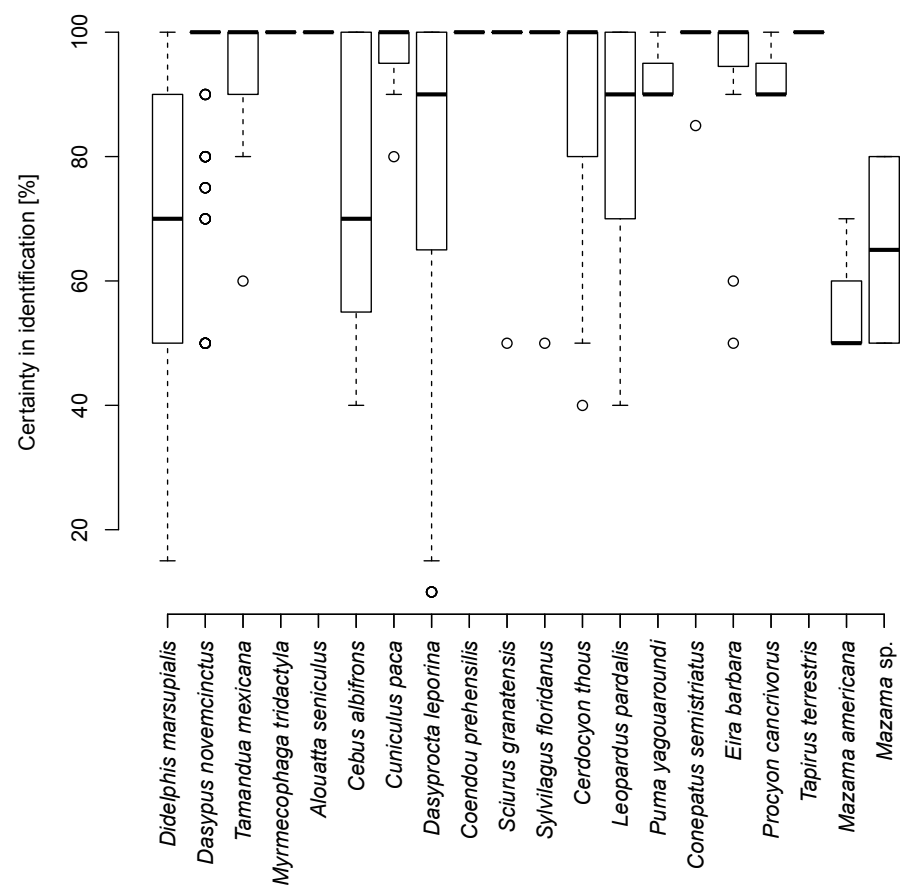

Figure 2. Certainty in the identification of species captured with camera traps. Box Plot indicating the distribution of percent certainty of images for each species. Species are arranged according taxonomically. of 27 species detected in the field (Table 2). The three collections reviewed and the publication of Osgood (1912) yielded eight and 18 species, respectively, although the localities include a broader and inaccurate region. The work of Linares (1998) contributed the largest number of species (29), but is inaccurate as to the original sources of records; maps involve poor resolution that also restrains an accurate origin. The review of museum specimens and bibliography yielded a total of 35 species recorded. For their part, interviews recorded seven species. From all information sources related to the Burro Negro area, the preliminary list reaches 40 species of non-flying mammals belonging to 24 families and nine orders (Table 2). Sierra de Ziruma has 37 species and shares 33 with Burro Negro $\left(I_{s}=0.857\right)$, while the highlands of Baragua have 32 species and shares $28\left(l_{s}=0.778\right)$.

The months with the greatest number of species detected were June and July (13 and 14, respectively), coinciding with the months when the sampling area was extended by installing three cameras on the eastern side of the dam (Figure 3). Even after excluding these additional cameras, a high number of species (11) remained, with a high similarity between these two months $\left(I_{s}=0.833\right)$. The months with the lowest number of species recorded were April and May, with six species; the absence of primates (Cebus albifrons and Allouatta seniculus), marsupials (Didelphis marsupialis), and mapurite (Amazonian hog-nosed skunk, Conepatus semistriatus; Figure 3) is worth noting. The composition of species remained more stable between September and February (inter-month $\mathrm{I}_{\mathrm{s}}>0.7$ ) and was slightly more variable the rest of the year $\left(I_{s}<0.7\right.$, except for June and July).

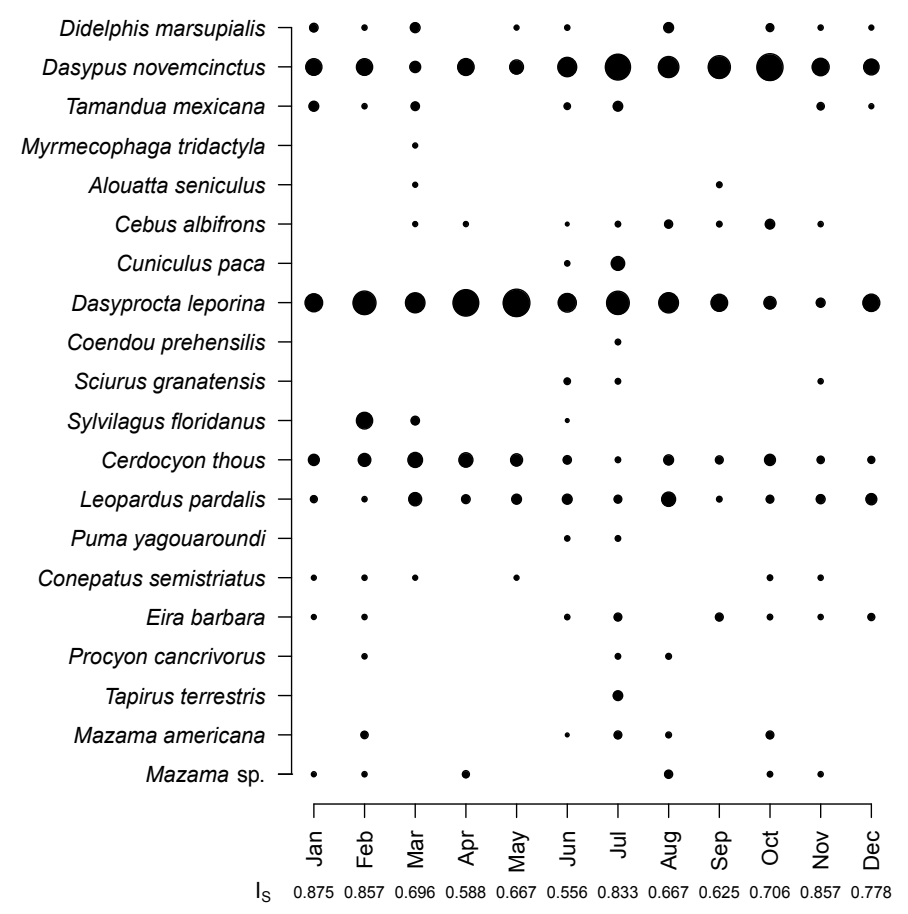

Figure 3. Frequency of monthly activity, expressed as the number of events adjusted for sampling effort (i. e., active camera-trap days) for each species detected throughout a year of sampling. Circle size is proportional to frequency of activity. For each month, the value of the Sørensen index $\left(I_{s}\right)$ is indicated with respect to the previous month. 


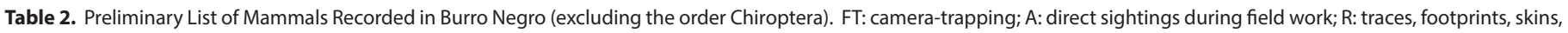

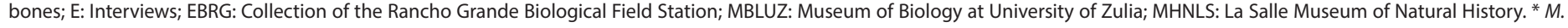
gouazoubira (Fischer, 1814) or M. nemorivaga (Cuvier, 1817), see comments in Gutiérrez et al. (2017).

\begin{tabular}{|c|c|c|c|}
\hline Order & Family & Species & Evidence \\
\hline \multirow[t]{2}{*}{ Didelphimorphia } & \multirow[t]{2}{*}{ Didelphidae } & Didelphis marsupialis (Linnaeus, 1758) & FT, A, Osgood (1912), Linares (1998) \\
\hline & & Marmosa robinsoni (Bangs, 1898) & EBRG, Linares (1998) \\
\hline Cingulata & Dasypodidae & Dasypus novemcinctus (Linnaeus, 1758) & FT, A, R, E, Linares (1998) \\
\hline \multirow[t]{4}{*}{ Pilosa } & Megalochynidae & Choloepus hoffmanni (Peters, 1858) & MHNLS \\
\hline & \multirow[t]{3}{*}{ Myrmecophagidae } & Tamandua mexicana (Saussure, 1860) & FT, A, R, MHNLS, Linares (1998) \\
\hline & & Tamandua tetradactyla (Linnaeus, 1758) & Osgood (1912) \\
\hline & & Myrmecophaga tridactyla (Linnaeus, 1758) & FT, E, Osgood (1912) \\
\hline \multirow[t]{4}{*}{ Primates } & Aotidae & Aotus griseimembra (Eliot, 1912) & E, MHNLS \\
\hline & \multirow[t]{2}{*}{ Atelidae } & Alouatta seniculus (Linnaeus, 1766) & FT, A, E, MBLUZ, Osgood (1912), Linares (1998) \\
\hline & & Ateles hybridus (Geoffroy, 1829) & A, E, Linares (1998) \\
\hline & Cebidae & Cebus albifrons (Humboldt, 1812) & FT, E, MHNLS, Osgood (1912), Linares (1998) \\
\hline \multirow[t]{14}{*}{ Rodentia } & Caviidae & Hydrochoerus hydrochaeris (Linnaeus, 1766) & E, Osgood (1912), Linares (1998) \\
\hline & Cuniculidae & Cuniculus paca (Linnaeus, 1766) & $\mathrm{FT}, \mathrm{E}$ \\
\hline & \multirow[t]{7}{*}{ Cricetidae } & Sigmodon alstoni (Thomas, 1880) & Osgood (1912), Linares (1998) \\
\hline & & Rhipidomys venezuelae (Thomas, 1896) & Linares (1998) \\
\hline & & Oligoryzomys fulvescens (Saussure, 1860) & Linares (1998) \\
\hline & & Neacomys tenuipes (Thomas, 1900) & Linares (1998) \\
\hline & & Necromys urichi (Allen \& Chapman, 1897) & Linares (1998) \\
\hline & & Oecomys speciosus (Allen \& Chapman, 1893) & Linares (1998) \\
\hline & & Zygodontomys brevicauda (Allen \& Chapman, 1893) & Linares (1998) \\
\hline & Dasyproctidae & Dasyprocta leporina (Linnaeus, 1758) & FT, A, E, Osgood (1912), Linares (1998) \\
\hline & Echimyidae & Proechimys guairae (Thomas, 1901) & Osgood (1912) \\
\hline & Erethizontidae & Coendou prehensilis (Linnaeus, 1758) & $\mathrm{FT}, \mathrm{A}$ \\
\hline & Heteromyidae & Heteromys anomalus (Thompson, 1815) & Osgood (1912), Linares (1998) \\
\hline & Sciuridae & Sciurus granatensis (Humboldt, 1811) & FT, A, MBLUZ, MHNLS, Osgood (1912), Linares (1998) \\
\hline Lagomorpha & Leporidae & Sylvilagus floridanus (Allen, 1890) & $F T, A, E$ \\
\hline \multirow[t]{9}{*}{ Carnivora } & Canidae & Cerdocyon thous (Linnaeus, 1766) & FT, A, E, Osgood (1912), Linares (1998) \\
\hline & \multirow[t]{4}{*}{ Felidae } & Leopardus pardalis (Linnaeus, 1758) & FT, R, E, Osgood (1912), Linares (1998) \\
\hline & & Panthera onca (Linnaeus, 1758) & R, E, Linares (1998) \\
\hline & & Puma yagouaroundi (Goeffroy, 1803) & $F T, A, E$ \\
\hline & & Puma concolor (Linnaeus, 1771) & Linares (1998) \\
\hline & Mephitidae & Conepatus semistriatus (Boddaert, 1785) & FT, Osgood (1912), Linares (1998) \\
\hline & Mustelidae & Eira barbara (Linnaeus, 1758) & FT, A, E, Osgood (1912), Linares (1998) \\
\hline & \multirow[t]{2}{*}{ Procyonidae } & Procyon cancrivorus (Cuvier, 1798) & FT \\
\hline & & Potos flavus (Schreber, 1774) & E, Linares (1998) \\
\hline Perissodactyla & Tapiridae & Tapirus terrestris (Linnaeus, 1758) & FT, E, Osgood (1912), Linares (1998) \\
\hline \multirow[t]{4}{*}{ Artiodactyla } & \multirow[t]{3}{*}{ Cervidae } & Mazama americana (Erxleben, 1777) & FT, Osgood (1912), Linares (1998) \\
\hline & & Mazama sp.* & FT, Linares (1998) \\
\hline & & Odocoileus virginianus (Zimmermann, 1780) & E, Osgood (1912), Linares (1998) \\
\hline & Tayassuidae & Pecari tajacu (Linnaeus, 1758) & E, MHNLS \\
\hline
\end{tabular}

For the species with sufficient records, which were detected in all months of the year (Dasyprocta leporina, Dasypus novemcinctus, Leopardus pardalis and Cerdocyon thous), it was possible to analyze the statistical differences throughout the year. For D. leporina and D. novemcinctus, detections were unevenly distributed throughout the year, even after adjusting for variations in sampling effort. D. leporina was observed significantly more frequently in the first half of the year $\left(X^{2}=40.786 ; P<0.001, d . f .=11\right)$. D. novem- cinctus was significantly more common in the second half of the year $\left(x^{2}=35.560 ; P<0.001, d . f .=11\right)$. In contrast, $L$. pardalis and $C$. thous showed no significant differences $\left(X^{2}=11.773 ; P=0.381 ;\right.$ d. $f .=11 ; X^{2}=14.777 ; P=0.193 ;$ d. $f$. $=11$, respectively). Sixteen events associated with reproductive behavior were recorded for nine species throughout the year of sampling; in the case of $D$. leporina these events did not occur within the period of higher frequency of detection. In the case of $C$. thous, a single mating event 


\begin{tabular}{llrll}
\hline Period & Camera & Date & \multicolumn{1}{c}{ Species } & \multicolumn{1}{c}{ Activity } \\
\hline P01 & C01 & $06 / 10 / 16$ & Sciurus granatensis & Pair of adults \\
P01 & C07 & $07 / 03 / 16$ & Tapirus terrestris & Adult with offspring \\
P02 & C02 & $07 / 12 / 16$ & Mazama americana & Offspring \\
P02 & C09 & $07 / 22 / 16$ & Dasyprocta leporina & Adult with offspring \\
P03 & C02 & $08 / 17 / 16$ & Mazama gouazoubira & Pair of adults \\
P03 & C09 & $08 / 20 / 16$ & Leopardus pardalis & Adult with offspring \\
P03 & C10 & $08 / 28 / 16$ & Dasyprocta leporina & Offspring \\
P03 & C05 & $09 / 08 / 16$ & Cerdocyon thous & Pair of adults \\
P04 & C10 & $09 / 15 / 16$ & Dasyprocta leporina & Offspring \\
P04 & C09 & $09 / 16 / 16$ & Eira barbara & Couple (adult with offspring?) \\
P04 & C09 & $11 / 01 / 16$ & Tamandua mexicana & Adult with offspring \\
P05 & C05 & $02 / 06 / 17$ & Mazama americana & Adult with offspring \\
P05 & C05 & $02 / 06 / 17$ & Mazama americana & Adult with offspring \\
P05 & C02 & $02 / 11 / 17$ & Cerdocyon thous & Copula \\
P06 & C09 & $04 / 23 / 17$ & Cerdocyon thous & Adult with offspring \\
P06 & C09 & $06 / 06 / 17$ & Cerdocyon thous & Two adults with offspring \\
\hline
\end{tabular}

Table 3. Events associated with reproductive behavior for the species recorded by camera trapping in Burro Negro, in chronological order.

was observed in February, and the presence of offspring was recorded in April and June 2017 (Table 3).

The analysis of the daily activity indicated that seven species were detected almost exclusively during daylight hours (between 06:00 $\mathrm{h}$ and 18:30 h), particularly primates, D. leporina, squirrel (Sciurus granatensis), ferret (Eira barbara), gray deer (Mazama sp.), and jaguarundi (Puma yagouaroundi; Figure 4). Eight were detected exclusively at night (19:00 h to 05:30 h). L. pardalis was spotted at night, but also in twilight hours and at dawn. Four species - red brocket deer (Mazama americana), northern tamandua (Tamandua mexicana), D. novemcinctus, and C. thous showed signs of activity in both periods. The first hours of nighttime (between $19 \mathrm{~h}$ and $21 \mathrm{~h}$ ) is the time of the day when more active species were observed (Figure 4).

\section{Discussion}

Camera trapping is a useful method for the study of terrestrial vertebrates involving low-cost equipment and short field work, thus offering a good cost/effectiveness that produces robust and reliable results on the richness and temporal patterns of species in an area (Balme et al. 2009). However, it requires proper planning to ensure high effectiveness. Failures in the operation of cameras and the number of non-informative photographic events (false positives or partial images) consume field and laboratory work time, which should be considered when planning studies at broad geographic scales. In our case, about $13 \%$ of field effort was lost due to equipment failures, and about $83 \%$ of laboratory work time was invested in the processing of non-informative photographic events.

Another aspect that influences the effectiveness of this method is the approach based on visual identification, which may be affected by taxonomic similarities, illumination and framing, camera sensitivity, and expertise of iden-

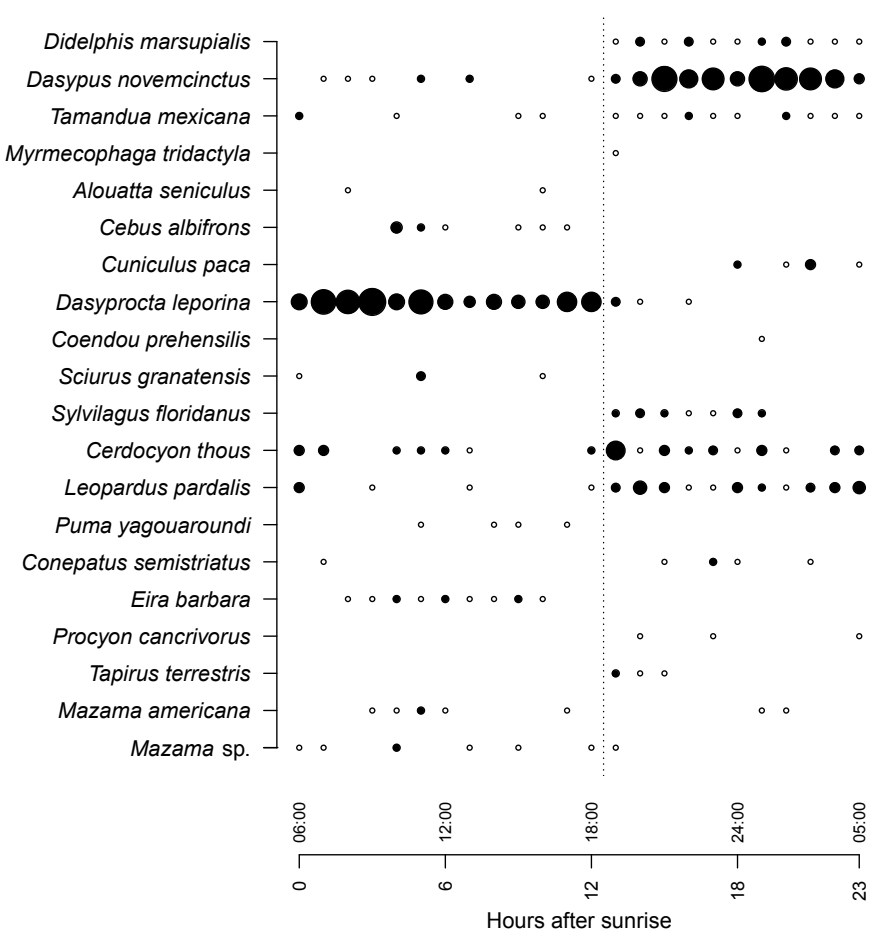

Figure 4. Frequency of daily activity, expressed as the number of events recorded for each species by time of day. Open circles indicate a single event; closed circles indicate more than one event. Circle size is proportional to frequency of activity.

tifiers (Barea-Azcon et al. 2007; Reyes et al. 2017). Therefore, it is advisable to include protocols that improve the certainty of identifications by persons with different training background (students, volunteers, or experts), or that are unaffected by differences in image quality (Meek et al. 2014). During the year of sampling, most (ca. $75 \%$ ) events were identified with high certainty; most identification issues were due to poor image quality, and only two species involved identification issues by morphological similarity.

The number of species detected was similar to the one derived from an inventory based on camera trapping performed in the Caura river, in southern Venezuela (PereraRomero et al. 2015), and was much larger than the eight species of mammals reported for Parcelación Lomalarga in the southwest of the Department of Valle del Cauca, Colombia (Mosquera-Munoz et al. 2015), an area with environmental characteristics that are similar to those in our study area. However, this only represents $50 \%$ of terrestrial mammals according to the sources consulted. Most of the differences between camera trapping and other sources relate to the list of small and medium-sized rodents that are difficult to capture, as these activate the camera less frequently and generally require being physically captured and identified by experts (Chaval et al. 2010; De Bondi et al. 2010; García et al. 2012; Herbreteau et al. 2011).

The jaguar (Panthera onca) is an iconic and highly valued species in conservation programs in the Neotropics (García et al. 2012). ZPBN is an important refuge area within the Maracaibo lake basin, given the high probability of occurrence and the low probability of extinction estimated (Jędrzejewski et al. 2017). However, jaguars were 
not recorded in this study. The available records are indirect (skins and interviews), and are probably two years old. The absence or low abundance of this species can only be determined with a more intensive and prolonged sampling effort (Hernández-Pérez et al. 2015).

Osgood (1912) mentions that the white tailed deer (Odocoileus virginianus) and the capybara (Hydrochoerus hydrochaeris) were common in savannas and wetlands of this region in the early twentieth century. Most likely, their populations have been seriously reduced due to overexploitation by hunting, thus being difficult to spot today (Correa-Viana 1991; Vaughan and Rodriguez 1997; Ojasti 2011). The rescue and protection of a remnant population of $H$. hydrochaeris could set the basis for a breeding program in a sector within the reservoir area, following the rational management model that has been implemented in the Western Orinoco Plains (Ojasti 2011). The photographic record of the tapir (Tapirus terrestris) confirms that this species still thrives in the study area, in spite of the negative trends reported for other zones of its range (Naveda-Rodríguez et al. 2012).

The phylogenetic analysis of deer has revealed a huge information gap restraining a precise definition of the distribution of M. gouazoubira and M. nemorivaga. so that the photographic record of gray deer (Table 2) cannot be identified accurately without a physical sample or additional evidence (Gutiérrez et al. 2017). Tamandua mexicana and T. tetradactyla have disjunct distributions, the former being present in Sierra de Ziruma (part of Serranía del Empalado; González-Fernández and Nieves 2011) and T. tetradactyla in Serrania de Baragua (Sanchez et al. 1995). The evidence of the presence of both species in the study area suggests an overlap in their distribution range. The population of Dasyprocta leporina inhabiting the Maracaibo lake eastern bank and the western portion of the States of Falcón and Lara appears to be isolated from the general distribution in the rest of the country, while $D$. punctata appears in the lake basin (Ojasti 1972). The records of D. leporina in Serrania de Baragua and Ojo de Agua El Cardon, to the northwest of our study area, are ambiguous, as pointed out by the authors themselves (Sanchez et al. 1995; Ferrer-Paris et al. 2015). Some of the photographic records assigned here as $D$. leporina with poor certainty could in reality correspond to $D$. punctata. In addition, it is the southernmost limit of the distribution of a disjunct population of Myrmecophaga tridactyla in the Maracaibo lake eastern banks (Linares 1998). Separately, no records are available for Cohendu prehensilis within $200 \mathrm{~km}$ of the study area (Linares 1998; GBIF Secretariat 2017).

One of the most valuable contributions of camera trapping is the continued and detailed recording - which cannot be achieved using other methods of active search or conventional traps - including the exact date and time of each capture event, hence providing useful data about the behavior of species (Ouboter Kadosoe and 2016). During 12 months of sampling, fluctuations in both the number of species detected and the detections by species were recorded (Figures 3 and 4), likely due to changes in activity or behavior patterns. The highest species richness was observed at the beginning of the sampling period, between June and August 2016, which corresponded to the early rainy season after a dry period with a high incidence of fires (Ferrer-Paris 2016a). The composition of species remained stable between September 2016 and February 2017 despite the changes in precipitation at the end of the rainy season and the beginning of the drought. The number of species detected declined between April and May 2017, at the beginning of another rainy season. This pattern is probably due to a sampling artifact. As cameras were located near water bodies, the detectability of animals was likely higher during the dry season, as these visited waterholes more frequently. In contrast, animals were probably more scattered during the rainy season as they were able to encounter water sources elsewhere, thus decreasing the probability of detection of cameras.

The sampling effort allowed visualizing a whole annual cycle and gather evidence of reproductive events for at least eight species (Table 3). The species that were detected throughout the year include D. leporina, which showed an increase in the number of detections during the driest semester of the year, a pattern that contrasts with the one observed for species of the same genus in other localities (Rocha et al. 2006; Jax et al. 2015; Ouboter Kadosoe and 2016). One possible explanation is that this species extends its period of activity in search of food, thus offsetting the temporary shortages of resources (Smythen 1978). It may also reflect a larger population size after the breeding season between July and September. Dasypus novemcinctus was detected more frequently in the wettest semester of the year, in line with reports for a different area (Rocha et al. 2006). It is likely that carnivores such as Cerdocyon thous and Leopardus pardalis show minor seasonal fluctuations, given their ability to adjust their diet to the resources available in different seasons of the year (Sunquist 1992).

Daily activity patterns often reflect the effect of the energy balance (food demand and supply) and the relationship between predators and prey (Schaik and Griffiths 1996), and can be altered by hunting pressure and modifications of the habitat that affect resource availability. The activity pattern of Leopardus pardalis showed a most intense activity at night, plus records in twilight hours, and isolated events during the day; this is consistent with the activity pattern reported by several authors (Ayala et al. 2010; Hernández-Pérez et al. 2015; Mosquera-Munoz et al. 2015; De la Torre et al. 2016). This pattern is probably influenced by the nocturnal activity of its potential preys, such as Didelphis marsupialis, Dasypus novenmcinctus, Tamandua mexicana and Sylvilagus floridanus (Martinez 2013). The few records of Puma yagouaroundi show a diurnal activity pattern that matches the activity of non-flying birds, which are reported as its most common prey (Mosquera-Munoz et al. 2015; Briones-Salas et al. 2016). 


\section{Acknowledgments}

The authors wish to thank M. Ferrer of the foundation "Ecoparque Refugio de Danta", J. Quintero, coordinator of research and environmental monitoring, and A. López, coordinator of the recreational area, of Burro Negro Recreational Park (INPARQUES, Zulia Region) all of whom assisted in field logistics and permits. Part of the equipment used was donated by Idea Wild to L. Garcia and I. Stachowicz. Several students of the LUZ Biology Museum collaborated in field trips. I. Stachowicz (IVIC) contributed part of the photographic equipment used and provided comments on some species. M. Quiroga (IVIC) provided comments and references for some species. Two anonymous reviewers contributed with comments and suggestions that improved the quality of the manuscript. María Elena Sánchez-Salazar translated the manuscript into English.

\section{Literature cited}

Ayala, G., Viscarra, E., and Wallace, R. 2010. Densidad y patrones de actividad del Ocelote (Leopardus pardalis) en Río Hondo, Parque Natural y área de manejo integrado Madidi, La Paz, Bolivia. Boletin ecológico y conservación ambiental 28:119129.

Balme, G. A., L. T. B. Hunter, And R. H. Slotow. 2009. Evaluating methods for counting cryptic carnivores. Journal of Wildlife Management 73:433-441.

Barea-Azcón, J. M., E. Virgós, E. Ballesteros-Duperón, M. Moleón, and M. CHIROSA. 2007. Surveying carnivores at large spatial scales: A comparison of four broad-applied methods. Biodiversity and Conservation 16:1213-1230.

Bevilacqua, M., L. Cárdenas, and D. A. Medina. 2006. Las áreas protegidas en Venezuela. Diagnóstico de su condición 1993 / 2004. Fundación Empresas Polar; Asociación Venezolana para la Conservacion de las areas Naturales (ACOANA). Caracas, Venezuela.

Briones-Salas, M., I. Lira-Torres, R. Carrera-Treviño, and G. SáchezRojAs. 2016. Abundancia relativa y patrones de actividad de los felinos silvestres en la selva de los Chimalapas, Oaxaca, México. Therya 7:123-134.

Chaval, Y., G. Dobigny, J. Michaux, M. Pagès, C. Corbisier, J.F. Cosson and V. Herbreteau. 2010. A multi-approach survey as the most reliable tool to accurately assess biodiversity: an example of thai murine rodents. Kasetsart Journal - Natural Science 44:590-603.

Consejo Zuliano de Planificación. 1975. Región Zuliana-República de Venezuela - Estudio para el Aprovechamiento Racional de los Recursos Naturales. Corporación Zuliana de Desarrollo, Departamento de Desarrollo Regional, Secretaria General de la Organización de los Estados Americanos. Washington, U. S. A. Disponible en: http://www.oas.org/dsd/publications/ unit/oea28s/begin.htm

Correa-VianA, M. 1991. Abundancia y manejo del venado caramerudo en Venezuela: evaluación inicial. Pp. 29-39 in El Venado en Venezuela, conservación, manejo, aspectos biológicos y legales (Fudeci, Profauna y Fedecave, eds.). Raúl Clemente Editores C. A. Valencia, Venezuela.
De Bondi, N., White, J. G., Stevens, M., And R. Cooke. 2010. A comparison of the effectiveness of camera trapping and live trapping for sampling terrestrial small-mammal communities. Wildlife Research 37:456-465.

De la Torre, J., P. Arroyo-Gerala, And L. Torres-Knoop. 2016. Density and activity patterns of ocelots in the Greater Lacandona Ecosystem. Therya 7:257-269.

FerRer-Paris, J. R. 2016a. Ubicación de los Incendios alrededor de la Reserva Nacional Hidráulica de Burro Negro y la Zona Protectora Machango, estado Zulia, Venezuela, entre enero 2015 y marzo 2016. figshare. Disponible en https://doi. org/10.6084/m9.figshare.3117031.v1

FerReR-Paris, J. R. 2016b. Cuatro métodos para la estimación de la densidad de población humana para el estado Zulia, República Bolivariana de Venezuela. Figshare. Disponible en https://doi.org/10.6084/m9.figshare.2095720.v2

Ferrer-Paris, J. R., I. Stachowicz, L. Morán, Y. González, A. Sánchez-Mercado, C. Lozano, J. A. Soto Villalobos, A. CardozoURDANETA, AND T. VARGAS. 2015. Caracterización ambiental del Ecoparque "Ojo de Agua El Cardón", municipio Miranda, estado Zulia. Figshare. Disponible https://doi.org/10.6084/ m9.figshare.1418273.v1

FuenMAYOR, W. 2005. Atlas del estado Zulia: Síntesis socio histórica, cultural y geográfica, quinta edición. Editorial Planos C. A. Maracaibo, Venezuela.

García, F. J., M. Delgado -Jaramillo, M. Machado, and L. Aular. 2012. Preliminary inventory of mammals from Yurubí National Park, Yaracuy, Venezuela with some comments on their natural history. Revista de Biología Tropical 60:459-472.

GBIF SeCRETARIAT. 2017. Coendou prehensilis (Linnaeus, 1758) in GBIF Backbone Taxonomy. Checklist dataset. Disponible en GBIF.org, https://doi.org/10.15468/39omei

GonzAlez-FernÁndez, M., AND J. A. Nieves. 2011. Inventario preliminar de fauna de los Cerros Socopó, Cerrón y Azúl, en la Sierra de Ziruma. Estados Falcón, Zulia. Serie Informes Técnicos ONDB DF/ IT/435. Ministerio del Poder Popular para el Ambiente. Maracay, Venezuela. Disponible en jr.ferrer.paris@gmail.com

Gutiérrez, E. E., K. M. Helgen, M. M. Mcdonough, F. Bauer, M. T. R. Hawkins, L. A. Escobedo-Morales, B. D. Patterson, and J. E. MaLDonAdo. 2017. A gene-tree test of the traditional taxonomy of American deer: the importance of voucher specimens, geographic data, and dense sampling. Zookeys 697:87-131.

HANDLEY, C. O. 1976. Mammals of the Smithsonian Venezuelan Project. Brigham Young University Science Bulletin, Biological Series 20:1-91.

Herbreteau V., S. Jittapalapong, W. Rerkamnuaychoke, Y. Chaval, J. Cosson, and S. Morand (eds.). 2011. Protocols for field and laboratory rodent studies. Kasetsart University Press. Disponible en CERoPath project: http://www.ceropath. org/FichiersComplementaires/Herbreteau Rodents protocols 2011.pdf

Hernández-Perez E., R. Reina-Hurtado, G. Castilo, M. Sanvicente, and J. Moreira-Ramirez. J. 2015. Fototrampeo de mamíferos terrestres de talla mediana y grande asociados a petenes del noroeste de la península de Yucatán, México. Therya 6:559-574. 
Jax, E., S. Marín, A. Rodríguez-Ferraro, and E. Isasi-Catalá. 2015. Habitat use and relative abundance of the Spotted Paca Cuniculus paca (Linnaeus, 1766) (Rodentia: Cuniculidae) and the Red-rumped Agouti Dasyprocta leporina (Linnaeus, 1758) (Rodentia: Dasyproctidae) in Guatopo National Park, Venezuela. Journal of Threatened Taxa 7:6739-6749.

Jędrzejewski, W., E. O. Boede, M. Abarca, A. Sánchez-Mercado, J.R. Ferrer-Paris, M. Lampo, G. Velásquez, R. Carreño, Á. L. Viloria, R. Hoogesteijn, H.S. Robinson, I. Stachowicz, H. Cerda, M. del M. Weisz, T. R. Barros, G. A. Rivas, G. Borges, J. Molinari, D. Lew, H. Takiff, AND K. SCHMidT. 2017. Predicting carnivore distribution and extirpation rate based on human impacts and productivity factors; assessment of the state of jaguar (Panthera onca) in Venezuela. Biological Conservation 206:132-142.

Legendre, P., AND L. Legendre. 1998. Numerical Ecology, segunda edición. Elsevier. New York, U. S. A.

LINARES, O. J. 1998. Mamíferos de Venezuela. Sociedad Conservacionista Audubon de Venezuela. Caracas, Venezuela.

Martínez, A. 2013. Patrones de actividad y densidad del ocelote (Leopardus pardalis) en la reserva de la biosfera "Sierra del Abra Tanchipa", San Luis Potosí, México. Registro en la Red Mexicana de Repositorios Institucionales. Colegio de Postgraduados, Tesis de Maestria. Disponible en: http://www. remeri.org.mx/portal/REMERI.jsp?id=oai:www.biblio.colpos. mx:10521/1909. Consultado el 08-08-2018.

Meek, P.D., G. Ballard, A. Claridge, R. Kays, K. Moseby, T. O\&\#39; Brien, A. O\&\#39; Connell, J. Sanderson, D.E. Swann, M. Tobler, AND S. TOWNSEND. 2015. Reccomended guiding principles for reporting on camera trapping research. Biodiversity and Conservation 23: 2321-2343.

Mosquera-Muñoz D., G. Corredor, P. Cardona, And I. Ambrecht. 2015. Fototrampeo de aves caminadoras y mamíferos asociados en el pie de monte de Farallones de Cali. Boletín científico de Museo de Historia Natural 18:144-156.

Navarro, J. F., AND J. Muñoz. 2000. Manual de huellas de algunos mamíferos terrestres de Colombia. Multimpresos. Medellín, Colombia. Disponible en https://rastreocolombia.jimdo.com/ guias/manual-de-huellas-de-algunos-mam\%C3\%ADferosterrestres-de-colombia/

Naveda-Rodríguez, A., P. A. Bermúdez, and F. Bisbal. 2012. Abundancia de Tapirus terrestris (Perissodactyla, Tapiridae) en la Cordillera de la Costa Central, Venezuela. Anartia 24:74-82.

Noguera-Urbano, E. A., and T. Escalante. 2015. Áreas de endemismo de los mamíferos (Mammalia) Neotropicales. Acta Biológica Colombiana 20:47-65.

OJASTI, J. 1972. Revisión preliminar de los picures o agutíes de Venezuela (Rodentia, Dasyproctidae). Memorias de la Sociedad de Ciencias Naturales La Salle 32:159-204.

OJASTI, J. 2011. Estudio biológico del chigüire o capibara, segunda edición. Equinoccio Acfiman. Caracas, Venezuela.

OsGood, W. H. 1912. Mammals from western Venezuela and eastern Colombia. Field Museum of Natural History, Zoological Series 10:33-66. Disponible en: http://dx.doi. org/10.5962/bhl.title.2647

OUBOter, P. E., AND V. S. KADOSOE. 2016. Three years of continuous monitoring of the large terrestrial mammals of Brownsberg Nature Park, Suriname. Academic Journal of Suriname 7:643-660.
Perera-Romero, L., J. Polisar, and L. Maffel. 2015. Grandes vertebrados terrestres en tierras ancestrales indígenas del alto Caura: importancia de los acuerdos comunitarios para la conservación del Escudo Guayanes venezolano. Pp. 185-204 in Conservación de grandes vertebrados en áreas no protegidas de Colombia, Venezuela y Brasil (Payan, E., C. A. Lasso, and C. Castano-Uribe, eds.). Instituto de Investigación de Recursos Biológicos Alexander von Humboldt. Bogotá, D. C., Colombia. Pietrangeli, M., A. Villarreal, and B. Gil. 2011. Florística de las comunidades forestales de zonas aledañas al embalse Pueblo Viejo (Burro Negro), estado Zulia, Venezuela. Boletín del Centro de Investigaciones Biológicas 45:237-286.

Portillo-Quintero, C. A., A. M. Sánchez, C. A. Valbuena, Y. Gonzalez, AND J. T. LARREAL. 2012. Forest cover and deforestation patterns in the Northern Andes (Lake Maracaibo Basin): a synoptic assessment using MODIS and Landsat imagery. Applied Geography 35:152-163.

Reyes, A., D. Rodríguez, N. Reyes-Amaya, D. Rodríguez-Castro, H. Restrepo, and M. Urguijo. 2017. Comparative efficiency of photographs and videos for individual identification of the Andean bear (Tremarctos ornatus) in camera trapping. Therya 8:83-87.

RoberTS, N.J. 2011. Investigation into survey techniques of large mammals: Surveyor competence and camera-trapping vs. transect-sampling. Bioscience Horizons 4:40-49.

Rocha, E.C., E. Silva, S. V. Martins, F. CÂndido, and C. Barreto. 2006. Evaluación estacional de la riqueza y abundancia de especies de mamíferos en la Reserva Biológica Municipal "Mário Viana”, Mato Grosso, Brasil. Revista de Biología Tropical 54:879-888.

Rodríguez, J.P., F. Rojas-SuÁrez, and D. GiRaldo-Hernández. 2010. Libro Rojo de los Ecosistemas Terrestres de Venezuela. Provita, Compañía Shell de Venezuela, Lenovo. Caracas, Venezuela.

Ruggiero, A., J. H. LAWton, AND T. M. BlackBurn. 1998. The geographic ranges of mammalian species in South America: Spatial patterns in environmental resistance and anisotropy. Journal of Biogeography 25:1093-1103.

Sánchez, J., A. Bermúdez, A. Ospino, V. Peña, R. Rivero, A. Pérez, G. Pérez, AND J. TRejo. 1995. Informe del inventario de fauna silvestre en la serranía de Baragua, edo. Lara. Diagnóstico preliminar del estado del área. Ministerio del Ambiente y los Recursos Naturales Renovables. Maracay, Venezuela. Disponible en http://diversidadbiologica.minamb.gob.ve/ media/bibliotecas/biblioteca 660.pdf

Smith, R.F., and A. Field. 2001. Aspectos de la ecología de Gyranthera caribensis Pittier (Bombacaceae) y su implicación en la conservación de algunos bosques del Norte de Venezuela. Acta Botanica Venezuelica 24:144-202.

SUnquist, M. 1992. The ecology of ocelot: the importance of incorporating life history traits into conservation plans. Pp. 117-128 in Memorias del simposio Felinos de Venezuela, Biología, Ecología y Conservacion. Fudeci. Caracas, Venezuela. SMrthen, N. 1978.- The natural history of the Central American agouti (Dasyprocta punctata). Smithsonian Contributions to Zoology 257:1-48. Disponible en https://doi.org/10.5479/ si.00810282.257

VAN SChalK, C.P., AND M. GRIFFITHS. 1996. Activity periods of indonesian rain forest mammals. BIOTROPICA 28:105-112. 
VAUGHAN, C., AND M. Rodríguez. 1997. Administración del venado de cola blanca en Costa Rica. Pp. 341-353 en Uso y Conservación de la Vida Silvestre Neotropical (Robinson, J. G., K. H. Redford, and J. E. Rabinovich, eds.). Fondo de Cultura Económica. Ciudad de México, México.

Wilson, D. E., And D. M. Reeder. 2005. Mammals Species of the World: A taxonomic and geographic reference, tercera edición. The Hopkins University. Baltimore, U. S. A.

Associated editor: Pablo Teta

Submitted: April 23, 2018; Reviewed: junio 20, 2018;

Accepted:August 25, 2018; Published on line: September 12, 2018. 